\title{
THE EFFECT OF SECTION 1446(b) ON THE NONRESIDENT'S RIGHT TO REMOVE
}

The general removal statute of the 1948 Judicial Code ${ }^{1}$ allows removal by a nonresident defendant ${ }^{2}$ in any civil action where the federal district court would have had original jurisdiction by virtue of diversity of citizenship. ${ }^{3}$ But, when a resident plaintiff joins a resident and a nonresident as codefendants in an action in state court, the nonresident defendant cannot initially remove the case to a federal forum, ${ }^{4}$ unless the joinder is fraudulent ${ }^{5}$ or the nonresident defendant

128 U.S.C. $\$ 1441$ (1964). The removal statute provides:

(a) Except as otherwise expressly provided by Act of Congress, any civil action brought in a State court of which the district courts of the United States have original jurisdiction, may be removed by the defendant or the defendants, to the district court of the United States for the district and division embracing the place where such action is pending.

(b) Any civil action of which the district courts have original jurisdiction founded on a claim or right arising under the Constitution, treaties or laws of the United States shall be removable without regard to the citizenship or residence of the parties. Any other such action shall be removable only if none of the parties in interest properly joined and served as defendants is a citizen of the State in which such action is brought.

(Emphasis added.) Subsection (c) provides for removal of a "separate and independent claim or cause of action." For a fuller discussion of subsection (c), see note 6 infra.

2 Unless they are waived by plaintiff, the removing defendant must comply with certain procedural requirements contained in 28 U.S.C. $\$ 1446$ (Supp. I, 1965). Failure strictly to comply with any of these requirements will defeat removal. See, e.g., Kovell v. Pennsylvania R.R., 129 F. Supp. 906 (N.D. Ohio 1954); Hamilton v. Hayes Freight Lines, 102 F. Supp. 594 (E.D. Ky. 1952). Section 1446 requires the removing defendant to file "a verified petition containing a short and plain statement of the facts which entitle him or them to removal," within thirty days after receipt by the defendant of the initial pleading, or thirty days after receipt of summons if such pleading is not required to be served on the defendant. In addition, the petition must be accompanied by a bond to cover the costs of the removal proceedings if the case is not removable. Finally, the defendant must give notice to all adverse parties and to the state court. 328 U.S.C. $\$ 1332$ (1964) :

(a) The district courts shall have original jurisdiction of all civil actions where the matter in controversy exceeds the sum or value of $\$ 10,000$, exclusive of interest and costs, and is between-

(1) citizens of different States . . . .

The rule of complete diversity between all the defendants and all the plaintiffs was established in Strawbridge v. Curtiss, 7 U.S. (3 Cranch) 267 (1806) : "The court understands these expressions to mean, that each distinct interest should be represented by persons, all of whom are entitled to sue, or may be sued, in federal courts."

4 Peper v. Fordyce, 119 U.S. 469 (1886); Rand v. Walker, 117 U.S. 340 (1886); Southern Pac. Co. v. Haight, 126 F.2d 900 (9th Cir.), cert. denied, 317 U.S. 676 (1942).

5 The requirements for establishing fraudulent joinder are very stringent. If there is a possibility that the plaintiff has stated a cause of action against the resident defendant, the joinder is not fraudulent. The courts will not look to the motive of the plaintiff in this context-the defendant may be judgment-proof or an attempt to defeat diversity jurisdiction may be patently obvious. See Mecom v. Fitzsimmons Drilling Co., 284 U.S. 183 (1931) (motive is immaterial); Chicago, R.I. \& P.R.R. v. Whiteaker, 239 U.S. 421 (1915) (irrelevant that defendant is judgment-proof); Uudley v. Community Pub. Serv. Co., 108 F.2d 119 (5th Cir. 1939) (doubt resolved in favor of plaintiff). 
is sued upon "a separate and independent claim or cause of action." 6 If the resident defendant ceases to be a party to the action, however, complete diversity is created and the question arises whether the nonresident defendant may then remove the case.

The answer to this question is not uniform, since the fact that diversity has been created is not solely determinative of the right to remove; the manner in which diversity was created is also considered by the courts. Moreover, the courts have differed as to what facts will allow a defendant to remove successfully. The source of this conflict is the 1949 amendment to the Judicial Code, which makes express provision for removal in those cases which are not removable initially. This section provides, in relevant part:

If the case stated by the initial pleading is not removable, a petition for removal may be filed within thirty days after receipt by the defendant, through service or otherwise, of a copy of an amended pleading, motion, order or other paper from which it may first be ascertained that the case is one which is or has become removable. ${ }^{7}$

In order to appreciate fully the nature of the controversy, however, a brief discussion of the case law prior to the amendment of section 1446 (b) is essential.

Before 1949 there was no statutory provision providing for removal where the grounds for removal arose subsequent to the commencement of a suit. The courts had developed their own doctrine

B 28 U.S.C. $\$ 1441$ (c) (1964). This provision states:

Whenever a separate and independent claim or cause of action, which would be removable if sued upon alone, is joined with one or more otherwise non-removable claims or causes of action, the entire case may be removed and the district court may determine all issues therein, or, in its discretion, may remand all matters not otherwise within its original jurisdiction.

This section was an attempt by the drafters of the Judicial Code to make the requirements for removal more stringent. Previously, if the plaintiff stated a "separable controversy," 36 Stat. 1094 (1911), the defendant could remove. For example, under the old statute, if plaintiff alleged liability severally, the nonresident defendant was permitted to remove; under the new section no such right would be available. Compare City of Gainesville v. Brown-Crummer Inv. Co., 277 U.S. 54 (1928), with Gray v. New Mexico Military Institute, 249 F.2d 28 (10th Cir. 1957). For the definitive discussion of the difference, and a definition of "separate and independent," see American Fire \& Cas. Co. v. Finn, 341 U.S. 6 (1951). Since this basis of removal has been limited, the nonresident's ability to remove on the basis of diversity becomes more important.

728 U.S.C. $\$ 1446$ (b) (Supp. I, 1965). This amendment is the second paragraph of the subsection. The first paragraph was part of the Code as originally passed in 1948. It provides:

The petition for removal of a civil action or proceeding shall be filed within thirty days after the receipt by the defendant, through service or otherwise, of a copy of the initial pleading . . or within thirty days after the service of summons upon the defendant if such initial pleading has then been filed in court and is not required to be served on the defendant, whichever period is shorter. 
to decide cases which became removable only after the statutory deadline required by the general removal provision of the Judiciary Act. ${ }^{8}$ This doctrine was the outgrowth of two cases decided by the Supreme Court. In the first, Powers v. Chesapeake \& $O . R y .{ }^{9}$ a personal injury suit, plaintiff had voluntarily dismissed the resident defendants at the beginning of the trial. The court held that the nonresident defendant had the right to remove the case to federal court, stating that "the incidental provision as to time," the requirement that the defendant must remove within the time allowed by the state court to answer the complaint, "must, when necessary to carry out the purpose of the statute, yield to the principal enactment as to the right." The court construed the statute as allowing the defendant to petition for removal "as soon as the action assumes the shape of a removable case in the court in which it was brought." 10

In Whitcomb $v$. Smithson, ${ }^{11}$ another personal injury case decided two years after Powers, the resident defendant railroad was granted a directed verdict at the close of all testimony, and the nonresident defendant receivers asked that the case be removed to federal court. The Supreme Court upheld a denial of the request, stating that a directed verdict "was adverse to the plaintiff and without his assent." 12 In the next three cases in which a resident defendant was dismissed without the plaintiff's assent, the Supreme Court based its denial of removal on two factors-the involuntary nature of the removal and the fact that the plaintiff still had a right to maintain an appeal of the court's action. ${ }^{13}$ Eventually, however, the lower courts disregarded

836 Stat. 1095 (1911). This statute required the filing of a removal petition "at the time, or any time before the defendant is required by the laws of the State or the rule of the State court in which such suit is brought to answer or plead to the declaration or complaint of the plaintiff . . . ." In addition, the verified petition for removal was to be filed in the state court from which it was to be removed, unlike the procedure today. Ibid.

9169 U.S. 92 (1898).

$10 I d$. at 101.

11175 U.S. 635 (1900).

$12 I d$. at 638 .

13 American Car \& Foundry Co. v. Kettelhake, 236 U.S. 311 (1915); Lathrop, Shea \& Henwood Co. v. Interior Constr. \& Improvement Co., 215 U.S. 246, 248 (1909); Kansas City Suburban Belt Ry. v. Herman, 187 U.S. 63 (1902) (by implication). In Kettelhake, Mr. Justice Day said:

[W] here there is a joint cause of action against defendants resident of the same State with the plaintiff and a non-resident defendant, it must appear to make the case a removable one as to a non-resident defendant because of dismissal as to resident defendants that the discontinuance as to such defendants was voluntary on the part of the plaintiff, and that such action has taken the resident defendants out of the case, so as to leave a controversy wholly between the plaintiff and the non-resident defendant. "Under the evidence in this case ... [the resident defendant] is not liable and in pursuance to that ruling you take a non-suit with leave to move to set the same aside; so that in my opinion he is still a party to the suit."

American Car \& Foundry Co. v. Kettelhake, 236 U.S. 311, 316 (1915). (Emphasis added.) 
the latter factor and merely applied the former. ${ }^{14}$ Thus was established the much criticized rule ${ }^{15}$ that if the resident defendant was dismissed from the case by the voluntary act of the plaintiff, the case became removable, but that if the dismissal was the result of either the defendant's or the court's acting against the wish of the plaintiff, the case could not be removed. This formula was applied with uniform consistency until the amendment of section $1446(\mathrm{~b})$ in $1949 .^{16}$ This amendment was the first statutory provision dealing with removal subsequent to the commencement of suit. Ironically, it was only when Congress spoke to the issue that the courts began to conflict in their handling of the problem.

A close reading of the authorities since the passage of the amendment to section $1446(\mathrm{~b})$ reveals three different views regarding the effect that the amendment should have on the voluntary-involuntary doctrine. The first view is that the amendment constitutes congressional overruling of the voluntary-involuntary line. Under this approach, the words of the statute are interpreted so that any "pleading,

14 See Halsey v. Minnesota-South Carolina Land \& Timber Co., 54 F.2d 933 (E.D.S.C. 1932) (resident defendant died pendente lite) ; Higgens v. Yellow Cab Co., 68 F. Supp. 453 (N.D. IIl. 1946) (resident defendant defaulted); Enochs v. Pitcairn, 55 F. Supp. 138 (W.D. Mo. 1944) (resident defendant receivers transferred company to nonresident). In each of these cases, removal was denied.

15 In most situations strict adherence to the voluntary-involuntary rule leads to a just result; however, it does so for the wrong reason. Moreover, there are situations where the result reached cannot be squared with the two relevant considerations in the area of removal-the nonresident's right to adjudicate in a federal forum and the extra cost, delay and duplication caused by removal. See generally text accompanying notes 47-50 infra; Note, Removal of Suits to Federal Courts After the Statutory Deadline, 60 HARv. L. REv. 959 (1947) ; Note, Federal Practice: Removal After Resident Defendant Is Involuntarily Dismissed, 17 OKLA. L. REv. 336 (1964).

See also ALI Study of THE Division of JuRIspiction § 1304 (Prop. Final Draft No. 1, April 1965). Given the premise that diversity jurisdiction should continue in the federal courts, the ALI study would allow a nonresident defendant to remove anytime he could remove if sued alone, under the theory that joinder with a resident is not a sufficient safeguard to the inherent prejudice toward a nonresident in state court. It is important to note, however, that the ALI study would also limit the situations in which defendants could claim that they are nonresidents. Id. $\$ 1301$ (b).

16 For examples of the dismissals found to be voluntary, see Southern Pac. Co. v. Haight, 126 F.2d 900 (9th Cir. 1942) (no service on resident and plaintiff elected to proceed against nonresident); Fogarty v. Southern Pac. Co., 121 Fed. 941 (S.D. Cal. 1903); Gable v. Chicago, M., St. P. \& P. R.R., 8 F. Supp. 944 (W.D. Mo. 1934) (settlement with resident defendants). But cf. Pullman Co. v. Jenkins, 305 U.S. 534 (1939) (not voluntary dismissal where there was no service on resident but plaintiff did not elect to continue against nonresident alone); Kincheloe v. Hopkins, 4 F. Supp. 196 (N.D. Okla. 1933) (not voluntary dismissal when plaintiff requested new trial against nonresident alone).

For examples of involuntary dismissal, see American Car \& Foundry Co. v. Kettelhake, 236 U.S. 311 (1915) (involuntary nonsuit); Lathrop, Shea \& Henwood Co. v. Interior Constr. \& Improvement Co., 215 U.S. 246 (1909) (dismissal by referee); Kansas City Suburban Belt Ry. v. Herman, 187 U.S. 63 (1902) (sustained demurrer to evidence); Henly v. Community Natural Gas Co., 24 F.2d 252 (N.D. Tex. 1928) (directed verdict).

In 1948, when Congress passed the Judicial Code, once again there was silence on the subject of removability subsequent to the commencement of a suit. 
motion, order or other paper" 17 which creates diversity will allow a nonresident defendant to remove.

Thus in Lyon v. Illinois Central R.R. ${ }^{18}$ plaintiff sued the railroad, a nonresident, to recover for personal injuries, and joined as a defendant the railroad's section foreman, a resident. At the conclusion of plaintiff's testimony in the state court, the resident defendant was dismissed. The corporate defendant then removed the case to federal court, and the plaintiff moved to remand on the ground that the resident defendant had been involuntarily dismissed. The court found that contention inappropriate in light of the section 1446(b) amendment:

Something must be read into this statute which Congress did not write into it before it can be said that a case can become removable from a state court during trial only in the event a plaintiff voluntarily does something to extricate and completely remove the resident from the suit. ${ }^{19}$

The opinion considered the order of the state court dismissing the resident defendant as an "order or other paper" within the terms of the statute. Since this order left the case as one of complete diversity, and thus a case over which the federal courts would have had original jurisdiction, the case was removable. Therefore, the court denied plaintiff's motion to remand.

The view that the 1949 amendment wrought a substantive change in the law was apparently also accepted in Bradley $v$. Halliburton Oil $W$ ell Cementing $\mathrm{Co}^{20}$ In that case, where plaintiff sued a nonresident company and its resident employee for injuries suffered in an automobile accident, the resident defendant died pendente lite, and the action against him was discontinued. The nonresident defendant removed and, on plaintiff's motion to remand, the court acknowledged that the plaintiff had not voluntarily dismissed the suit against the resident defendant. Notwithstanding this fact, the court overruled the motion to remand, because of the wording of section $1446(\mathrm{~b})$. The court understood the wording of the amendment to be clear and unambiguous, requiring removal whenever there is an appropriate change in circumstances. Although it found prior cases to be "helpful in

17 There have been cases determining what constitutes a "pleading, motion, order or other paper" for purposes of initiating removal. Stack v. Strang, 191 F.2d 106 (2d Cir. 1951) (dismissal of original complaint revealed United States as real defendant and was an "order"); Bonnel v. Seaboard Air Line R.R., 202 F. Supp. 53 (N.D. Fla. 1962) (letter from plaintiff's counsel demanding excess of jurisdictional amount in settlement not "other paper"; failure to answer request for admission of excess amount in controversy was); Gilardi v. Atchison, T. \& S.F. Ry., 189 F. Supp. 82 (N.D. Ill. 1960) (deposition is "other paper") ; Hamilton v. Hayes Freight Lines, 102 F. Supp. 594 (E.D. Ky. 1952) (answer by plaintiff in collateral proceeding is "other paper"); Waldron v. Skelly Oil Co., 101 F. Supp. 425 (E.D. Mo. 1951) (opening statement of plaintiff's attorney).

18228 F. Supp. 810 (S.D. Miss. 1964).

$19 \mathrm{Id}$. at 811 .

20100 F. Supp. 913 (E.D. Okla. 1951). 
determining the final outcome . . the present statutes necessarily must govern." 21

Despite Lyon and Bradley, the conclusion that the amendment to section 1446(b) was intended by Congress to do away with the voluntary-involuntary rule does not seem justified. It is true that the words of the statute, examined without referring to the legislative history, might be interpreted to sanction this result-i.e., it is not inconsistent with the words of the statute to hold that any "order" of a state court which creates diversity would make the case "removable." However, since the words of the statute do not compel such an interpretation, a court must look further to ascertain the intent of Congress. ${ }^{22}$ And an examination of the legislative history clearly demonstrates that the result in Lyon and Bradley is contrary to the purpose of the

21 Id. at 918. It should be noted that a decision in this case based on the voluntaryinvoluntary doctrine might not necessarily have resulted in remand, since, as this court understood :

It cannot be denied that plaintiff did not voluntarily dismiss the suit against the resident defendant . . . but it is just as clear that neither the state court nor either of the defendants took any active steps to remove . . . .

Id. at 917. However, in a case decided prior to the amendment, Halsey v. MinnesotaSouth Carolina Land \& Timber Co., 54 F.2d 933 (E.D.S.C. 1932), the court had denied removal when the resident defendant had died pendente lite. That court held that since plaintiff had no part in changing the status of the case, he should not be denied his right to proceed in the state court because of an event over which he had no control. The decision in Halsey has been criticized. "The court . . . woodenly denied removal because of the lack of voluntary dismissal by the plaintiff." 60 HARV. L. REv. 959, 961 (1947).

There is a third case, Parkhill Produce Co. v. Pecos Valley So. Ry., 196 F. Supp. 404 (S.D. Tex. 1961), which does not deal with the specific problem of removal when a resident defendant ceases to be a party to the suit, but which is significant nonetheless because an "involuntary" change in circumstances rendered the case removable. Specifically, defendant's successful motion to consolidate several causes of action, thereby creating the requisite jurisdictional amount, was held to allow removal. The court noted that nothing in the statute qualifies the word "order":

Nothing in the statute indicates that the "order" therein referred to must be one approved by all the parties, nor is there any indication in the statute that removal is necessarily limited to the voluntary acts of a plaintiff.

Id. at 406. Contra, Fried v. State Life Ins. Co., 10 F. Supp. 369 (W.D. La. 1933), a case decided prior to the amendment. See also Platt v. Illinois Cent. R.R., 305 F.2d 136, 139 (5th Cir. 1962) (dictum) :

If, in this case, that test results in a decision of the State Court that the suit should be dismissed as to Ellington [the resident defendant] the case then becomes removable to the Federal Court under the statute authorizing removal of cases of this character....

One of the textwriters indicates that the amendment might have brought about a change:

Prior to 1949 it was settled that a case did not become removable if the non-diverse party had been eliminated from the case by a directed verdict. The distinction was drawn between subsequent action by a court, which did not make a case removable, and voluntary action by the plaintiff which did. It is questionable whether this distinction has survived the 1949 amendment to the Judicial Code.

1 Barron \& Holtzoff, Federal Practice §103, at 474 (1960).

22 Indeed, even if the meaning of the statute is "plain," it should not be followed where the legislative history shows this meaning to be unreasonable. See MisHKIN \& MORRIS, ON LAW IN CourTs 340-47 (1965). 
amendment. The provision itself was enacted as part of a larger bill. ${ }^{23}$ This legislation was introduced in the House as making "not a single substantive change in the law. This is purely corrective [of the revision of titles 18 and 28 of the United States Code passed on June 25, 1948]." 24 Moreover, the explanatory note for section 1446(b), contained in the House Report, ${ }^{25}$ reinforces the necessary conclusion which must be drawn from the amendment's inclusion in corrective legislation. The House Report states:

The second paragraph of the amendment to subsection (b) is intended to make clear that the right of removal may be exercised at a later stage of the case if the initial pleading does not state a removable case but its removability is subsequently disclosed. This is declaratory of the existing rule laid down by the decisions. (See for example, Powers v. Chesapeake etc. Ry. Co., 169 U.S. 92.) ${ }^{26}$

The above statement is strong evidence that Congress did not intend that section 1446 (b) be considered a mandate to the courts to abolish the voluntary-involuntary doctrine.

If this is true, then what effect did Congress intend the amendment to have? There are two logical alternatives - either the amendment was meant to codify the voluntary-involuntary rule, or it did not speak to the issue at all; cases have adopted each of these views. The first alternative is reached by interpreting "the existing rule laid down by the decisions" 27 to be the voluntary-involuntary rule.

Thus in Lauf $v$. Nelson, ${ }^{28}$ where plaintiff sued for less than the jurisdictional amount, his insurance company intervened to collect an additional amount as indemnity. The aggregation of the two claims exceeded the jurisdictional amount, and the defendant removed. In upholding plaintiff's motion to remand, the court described section 1446(b):

Under this provision a suit not removable when filed may become removable by the voluntary act of the plaintiff through amendment of his pleadings, or dismissal, or discontinuance as to a party whose presence prevented removal. . . . On the other hand, any change of circumstances which is not brought about by the voluntary act of the plaintiff will not make an action removable. ${ }^{29}$

2363 Stat. 89 (1949).

2495 Cong. Rec. 6249 (1949).

25 H.R. ReP. No. 352, 81st Cong., 1st Sess. 1248 (1949).

$26 \mathrm{Id}$. at 1268.

27 Ibid.

28246 F. Supp. 307 (D. Mont. 1965).

$29 \mathrm{Id}$. at 311. (Emphasis added.) 
The view that the voluntary-involuntary distinction is codified by the amendment seems implicit in this statement.

In Squibb-Mathieson Int'l Corp. v. St. Paul Mercury Ins. Co., ${ }^{30}$ the statute was again interpreted as a codification of the voluntaryinvoluntary rule. Complete diversity was created here when the resident codefendant was dismissed on his own motion. The court upheld plaintiff's motion to remand because the dismissal was involuntary. Authority for the application of the voluntary-involuntary doctrine was found in the legislative history of the amendment. The court stated that the words "existing rule" in the House Report referred to the holding of Powers, and asserted that the holding in that case gave rise to the voluntary-involuntary rule. ${ }^{31}$

In addition to cases holding that the amendment codified the voluntary-involuntary rule, there are, as indicated above, decisions which treat the statute as merely enunciating the "procedural" rule that a petition for removal must be filed within thirty days after the defendant is informed that the case is removable. These cases interpret the amendment as not speaking to the issue of which changes will render a case removable, and thus as having no effect on the voluntary-involuntary rule.

For example, in Waldron $v$. Skelly Oil Co., ${ }^{32}$ the court held that the defendant had waived his right to remove by not removing upon the dismissal, by plaintiff, of the resident defendants, but waiting until plaintiff's counsel had concluded his opening statement. In discussing section 1446(b), the court stated: "The new removal statute was enacted primarily for the purpose of establishing uniformity of procedure with respect to removal and uniformity of time within which removal could be taken." ${ }^{33}$ This court understood the "existing rule" of Powers to be restricted to the principle that the defendant must "file a petition for removal as soon as the action assumes the shape of a removable case in the court in which it was brought." 34

A similar construction was given to the section in Strandholm $v$. General Constr. Co. ${ }^{35}$ Strandholm was the culmination of the following events: Plaintiff lost in the state trial court, but his request for a new trial against the nonresident defendants was granted by that court. The nonresident defendants then appealed the judgment granting a new trial, but the Oregon Supreme Court affirmed both this judgment and the dismissal of the resident defendants. At this juncture the nonresidents removed; but the federal court remanded,

30238 F. Supp. 598 (S.D.N.Y. 1965).

$31 \mathrm{Id}$. at 599.

32101 F. Supp. 425 (E.D. Mo. 1951).

33 Id. at 426.

34 Ibid.

35222 F. Supp. 12 (D. Ore. 1963). 
giving the voluntary-involuntary doctrine as one reason. ${ }^{36}$ The court made clear, however, that it did not find its authority for the application of the doctrine in the 1949 amendment, but rather in the prior case law. ${ }^{37}$

Similarly, in Cudney v. Midcontinent Airlines, Inc., ${ }^{38}$ plaintiff sued a nonresident corporate defendant and its resident pilot. The resident defendant was dismissed on the basis of nonliability. Defendant removed, and on plaintiff's successful motion to remand the court held that section 1446 (b) was merely procedural. However, removal was considered inappropriate because, among other reasons, "plaintiff has a right of appeal from the State Court's action. Consequently the case is still not one of diversity." " 39 Thus, while the result in Cudney is that which would have been reached had the voluntary-involuntary rule been inflexibly applied, it can be seen that when the amendment is interpreted as establishing only a uniform time requirement, the courts are able to adopt a more flexible approach in deciding which changes in a case will permit removal. ${ }^{40}$

Thus the major question left unresolved is whether the statute should be interpreted as a codification of the voluntary-involuntary rule or as the statement of a procedural rule. The words of the statute are not dispositive. Clearly the words can be interpreted as establishing no more than a thirty day requirement within which the defendant must remove after learning, from the contents of the enumerated papers, that the suit has become removable. Interpreted in this manner, the amendment leaves open the question of what circumstances will render a case removable. However, the words of the statute can also be interpreted as a codification of the voluntary-involuntary rule. To

36 The court's alternative ground for remand was the failure of the defendant to petition for removal within twenty days of notice (the time requirement in $\S 1446(\mathrm{~b})$ until amended, 79 Stat. 101 (1965)). Id. at 13.

37 The court cited American Car \& Foundry Co. v. Kettelhake, 236 U.S. 311 (1915), an early voluntary-involuntary case, and Moore's Federal Practice. The latter finds all his support for the application of the doctrine in the prior case law. See 1A Moore, Federal Practice 1243-44 (2d ed. 1965).

Although Strandholm is an excellent example of the complementary operation of the case law and the statute, it has been criticized as an example of the deficiencies of the voluntary-involuntary distinction. In this case, although the resident defendants had been permanently dismissed by the Supreme Court of Oregon, the federal court indicated that it would have denied removal even if the nonresident had complied with the twenty-day requirement. For an article inspired by this case, see 17 OKLA. L. REv. 336 (1964).

3898 F. Supp. 403 (E.D. Mo. 1951).

39 Id. at 405 .

40 Because the same results are often achieved for different reasons, it is sometimes difficult to tell whether a court is finding authority for the voluntary-involuntary rule in the prior case law or in the amendment itself. See, e.g., Viles v. Sharp, 248 F. Supp. 1019 (W.D. Mo. 1965). Of course, once a court has decided to apply the voluntary-involuntary doctrine, its source of authority is not especially important to the litigants. However, the fact that a court finds its authority in the prior case law, in the long run, may have a significant effect. It is only if the courts feel that they are free from a legislative mandate to apply this distinction, that the judicial development of suitable doctrines may occur in this area. See text accompanying notes 51-54 infra. 
do this, one must recognize that Congress was enacting this provision against the judicial background developed prior to 1949 . Then the phrase, "the case is one which is or has become removable," 41 can be interpreted as a reference to the voluntary-involuntary rule and its incorporation into the amendment. Although this latter interpretation seems somewhat strained because of the ease with which Congress might explicitly have sanctioned the voluntary-involuntary rule, the interpretation is plausible enough to warrant further investigation into the history of the amendment.

It is apparent from the prior analysis of the cases which adopt one or the other of these views that the major cause of the conflict has been the ambiguous statement in the House Report that the statute is "declaratory of the existing rule laid down by the decisions." Powers is cited in this same report as an example of the "decisions." The courts then resolve this dispute on the basis of their respective understandings of the holding in Powers.

Powers itself does not draw the distinction between voluntary and involuntary dismissals, although there the resident defendants were dismissed voluntarily. The real question before the court in Powers was "whether a defendant may file . . . a petition for removal, after the time mentioned in the act of Congress has elapsed, in a case which was not removable when that time expired." 42 This procedural question was decided in the affirmative, and is actually the holding of the case. However, it is also true that Powers, in conjunction with Whitcomb, has come to stand for the voluntary-involuntary rule. ${ }^{43}$ Thus, while the better view seems to be that Powers was cited by the House Report as an example of the procedural rule laid down in that case, this argument, in itself, is not dispositive.

Further evidence can be found for the proposition that section 1446 (b) was intended only to set up the procedural rule. Since the second paragraph of section 1446(b) was to be "corrective" of the Judiciary Act of 1948, the statutory purpose of the first paragraph of the section, which was part of the 1948 act, is especially relevant. Because of the problems involved in the prior procedure, where the petition for removal was filed in the state court and the time provisions varied," the intent of this provision was to "give adequate time and operate uniformly throughout the Federal jurisdiction." 45 Since the amendment in controversy is set up as a parallel provision, to cover the situation where removability is not present at the commencement of an action, the only logical interpretation is that it, too, had as its sole

4128 U.S.C. $\$ 1446$ (b) (Supp. I, 1965).

42169 U.S. at 99.

43 See note 16 supra.

44 See note 8 supra.

45 Reviser's Notes following 28 U.S.C. \$1446 (1964); see Richlin Advertising Corp. v. Central Fla. Broadcasting Co., 122 F. Supp. 507, 509 (S.D.N.Y. 1954). 
purpose to provide a uniform time throughout the federal system. Thus Congress left the courts free to decide what changes in circumstances will allow a nonresident defendant to remove, and it would seem that the federal courts are abdicating an important responsibility when they view the statute as a mandate. ${ }^{46}$

Although the courts have never articulated any reason for the voluntary-involuntary rule, the rule does have merit in those cases where it avoids the expense, delay and duplication which would result if a nonresident defendant were allowed to remove any time he was forced to defend, without the presence of a resident defendant, in a state forum. ${ }^{47}$ Voluntary dismissals rarely, if ever, occur after the start of a trial; involuntary dismissals usually do. Thus, in most cases where removal is justified, in that it would not cause delay, expense or duplication, it is allowed under the voluntary-involuntary rule. However, situations can arise where the involuntary dismissal of the resident defendant occurs at a time when judicial efficiency would not suffer if removal were allowed. For example, when a new trial is ordered for the nonresident defendant alone ${ }^{48}$ or when the resident defendant defaults at the commencement of the trial, ${ }^{49}$ there seems to be no reason to deny a petition for removal..$^{50}$ If the courts were to adopt the position that the 1949 amendment was merely procedural, a more flexible doctrine could be articulated which would better balance the court's interest in avoiding cost, delay and duplication-the only rational reason for having the voluntary-involuntary rule-with the defendant's interest in removal. Such a flexible rule might provide that if the federal court, in its discretion, feels that the granting of removal would impair the operation of the judicial machinery because of the stage which the proceedings in state court have reached, the

46 Of course, to the extent that courts feel compelled by the principle of stare decisis to adhere rigidly to the voluntary-involuntary rule, it will make little difference whether they view the amendment as a codification of that rule, or as a merely "procedural" measure having no effect upon the rule.

47 Another possible argument for the voluntary-involuntary rule is the traditional right of plaintiff to choose his forum. This traditional right, however, does not carry with it an absolute right to remain in the forum chosen. Thus in the situation where a resident plaintiff chooses to sue a nonresident defendant in state court, Congress has made the judgment that the threat of prejudice to the nonresident defendant is sufficient to allow him to remove. 28 U.S.C. $\$ 1441$ (b) (1964).

Where a resident plaintiff joins both a resident and nonresident defendant in state court, the nonresident is not allowed to remove. Here it seems that Congress has made a judgment that participation by the resident defendant in the state court proceeding will protect the nonresident defendant from any prejudice which he might otherwise face. If the resident defendant is dismissed, whether voluntarily or involuntarily, the danger of prejudice to the defendant reappears; consequently, plaintiff's right to maintain his choice of forum becomes defeasible.

48 Strandholm v. General Constr. Co., 222 F. Supp. 12 (D. Ore. 1963).

49 Higgens v. Yellow Cab Co., 68 F. Supp. 453 (N.D. I11. 1946).

50 Although no cases have been found where a voluntary dismissal took place later than the commencement of the trial, were the voluntary-involuntary rule followed under such circumstances, the petition for removal would have to be allowed, despite the fact that the results would be contrary to the proffered rationale for the rule. 
court should remand. Thus if the resident defendant is dismissed by a directed verdict or a demurrer to plaintiff's evidence, the state court would retain jurisdiction. The same result should obtain if the resident defendant were dismissed from the case for any reason, and the plaintiff had an appeal pending. Not only is there ample precedent for this flexible approach, ${ }^{51}$ but the number of cases where the result would vary from that achieved under the present formula would be very small. The alternative presented here would not offer the predictability of the strict voluntary-involuntary rule; but, as shown earlier, ${ }^{52}$ it is not always clear whether the courts will find certain dismissals voluntary. Furthermore, this exercise of judicial discretion is entirely consistent with a similar authority granted the federal judiciary under section 1441 (c) of the Judicial Code. ${ }^{53}$ Under that provision, when a separate and independent claim which is removable is joined with other claims which are not, the whole proceeding is removed. Then the court, in its discretion, can remand all joined matters not within its original jurisdiction. ${ }^{34}$

Clearly, inflexible adherence to the voluntary-involuntary rule produces results which are difficult to justify on any sound basis. Judicial modification of the rule, however, will not be possible unless the courts confine the application of the amendment to section $1446(\mathrm{~b})$ in accordance with the limited purpose for which it was enacted.

61 See note 13 supra; Yulee v. Vose, 99 U.S. 539 (1878), a pre-Powers case in which a judgment in favor of the resident and nonresident defendants was reversed as to the latter. The nonresident was granted removal by the Supreme Court, although the resident was dismissed by the state court.

52 See, e.g., Pullman Co. v. Jenkins, 305 U.S. 534 (1939) ; Kincheloe v. Hopkins, 4 F. Supp. 196 (N.D. Okla. 1933); note 16 supra.

5328 U.S.C. $\$ 1441$ (c) (1964).

54 See, e.g., Twentieth Century-Fox Film Corp. v. Taylor, 239 F. Supp. 913 (S.D.N.Y. 1965) (part retained and part remanded) ; Fine v. Philip Morris, Inc., 239 F. Supp. 361 (S.D.N.Y. 1964) (part retained and part remanded); Baltimore Gas \& Elec. Co. v. United States Fidelity \& Guar. Co., 159 F. Supp. 738 (D. Md. 1958) (remand denied). 